\title{
PERSPECTIVE DEVELOPMENT OF THE GRAIN MARKET AND ITS REGULATION MECHANISM IN UKRAINE
}

\author{
Anatolii Dibrova, DSc, Professor'; Larysa Dibrova, PhD, Associate Professor; \\ Yaroslav Krylov, postgraduate student ${ }^{3}$; Maksym Dibrova, postgraduate student ${ }^{4}$
}

Faculty of Economics, National University of Life and Environmental Sciences of Ukraine

\begin{abstract}
The article gives an economic assessment of the current state of the grain industry development, determines the main factors influencing the formation of demand and supply on the grain market. The lack of efficiency of the mechanism of regulation of the grain market in Ukraine is substantiated on the basis of the obtained values of "market price support" indicators per $1 \mathrm{t}$ of grain and "nominal coefficient of protection of producers" used in the countries of the Organization for Economic Co-operation and Development (OECD). The forecasts of gross collections of cereals and legumes, as well as their volumes of domestic consumption in Ukraine for the period up to 2025 are estimated. The state of transport and logistics infrastructure of the grain market of Ukraine is estimated. Based on the analysis carried out, strategic guidelines for the development of the grain market and its regulation mechanism are proposed.
\end{abstract}

Key words: grain market, grain production, mechanism, state regulation, logistics, export potential JEL codes: Q13, Q18, O21

\section{INTRODUCTION}

In recent years, Ukraine has significantly increased grain production and entered the cohort of its major producers and exporters. Despite the positive dynamics, there are a number of problems that hinder its further development. In particular, infrastructure costs for grain exports remain at a rather high level, which reduces the competitiveness of domestic grain in the foreign market. The transport infrastructure does not quite meet the needs of the grain market due to the operation of the railway transport, the unpredicted increase in tariffs for the transportation of grain by rail, mainly the unsatisfactory state of highways, the lack of development of river transport. To date, the problem with logistics was less felt, since export volumes were significantly lower, and high grain prices with surplus blocked additional logistics costs. However, in the context of the decline in world prices observed during 2013-2017, the inefficiency of transport and logistics infrastructure on the grain market was significantly affected by the income of agricultural producers.

Positive tendencies to increase the volume of production and export of grain, accompanied by

${ }^{1}$ Corresponding author: dibrova@nubip.edu.ua

${ }^{2}$ Corresponding author: dibrova_larisa@ukr.net

${ }^{3}$ Corresponding author: ykrylov@ukr.net

${ }^{4}$ Corresponding author: max_dibrova@ukr.net 
instability of prices and incomes of commodity producers, monopolization of the market and over concentration of production by large companies, it is not always possible to balance the interests of the main market participants (producers, consumers and the state).

Practice shows that due to insufficient quality, Ukraine exports mostly cheap feed grain, while it is forced to import meat, meat and dairy products, and animal feed. From this point of view, the preservation of such trends shows that our state can remain an appendage of raw materials of developed countries, leaving them added value and creating new jobs for them. In this case, without structural changes in the agriculture sector of the domestic economy, in our opinion, it will be quite difficult to solve the problems of poverty, unemployment in the countryside and the revival and development of rural areas.

\section{MATERIALS AND METHODS}

During the research, the following methods were used: comparative analysis and expert assessments - for the analysis of quantitative and qualitative indicators of development of the domestic grain market in the conditions of globalization; statistical-economic - for the collection and processing of statistical data, studying the dynamics of exports and imports of grain; economics and mathematics - to predict the impact of demand factors (consumption on food and feed purposes, exports and stocks) and supply (yield, area, production, imports and stocks) on the grain market for the period up to 2025 .

In order to evaluate the effectiveness of agricultural policy and the level of domestic support of agriculture there was used the methodology which is applied in the country-members of Organization for Economic Co-operation and Development (OECD). The methodology of the quantitative estimation of the state support is substantiated in the works of such famous scientists as Josling (1973), Tsakok (1990), and Webb, Lopes and Penn (1990).

In a market economy, for the development of a balanced agriculture policy it is very important to correctly determine its effectiveness, directly for those who produce agricultural products. Having this aim and according to the methodology of the OECD, and the indicator "market price support" (MPS) is used, which determines the monetary value of gross transfers to producers from consumers and taxpayers for the year that arose as a result of the state policy means that creates a gap between prices for a certain kind of grain in the domestic and foreign markets (OECD, 2018) - Figure 1.

Indicator MPS is determined in producer prices and is calculated by the formula (OECD, 2018):

$$
M P S=\left(P_{p}-P_{w}\right) \cdot S_{1}
$$

where:

$P_{p}$ - internal price per unit of output;

$P_{w}-$ world price per unit of output;

$S_{1}$ - supply of the domestic market.

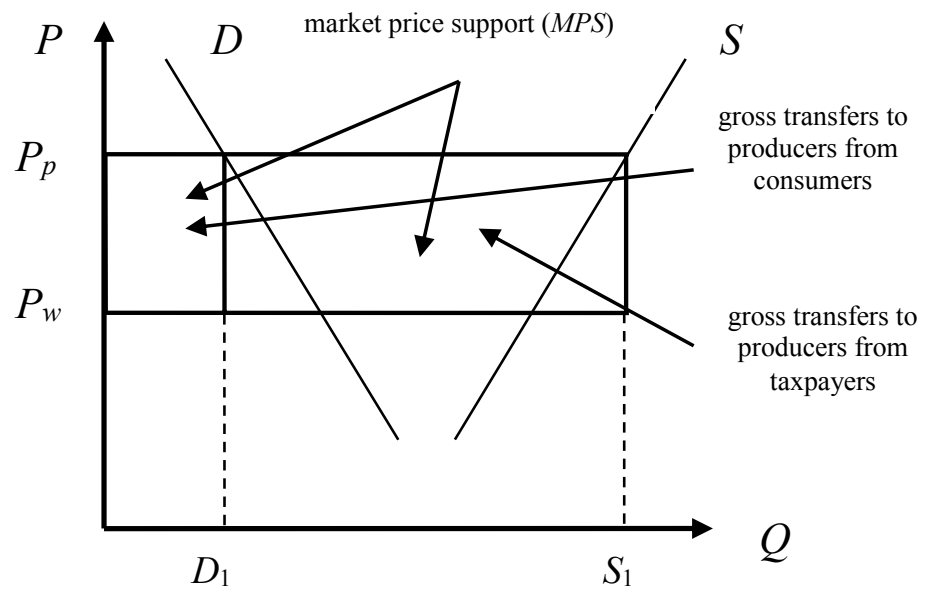

Figure 1. Market price support (MPS) for agricultural products 
In world practice, the effectiveness of state support of agricultural production is determined by comparing the domestic price for it with world market prices. This approach is based on the fact that without government intervention, that is for free competition in domestic and foreign markets the distinction between domestic and world prices would have disappeared. One of the simplest indicators assessing the level of state support is nominal protection coefficient (NPC) manufacturers, which evaluates only the ratio of domestic and world prices (OECD, 2018).

$$
N P C_{m}=\frac{P_{i}^{d}}{P_{i}^{r}}
$$

where:

$P_{i}^{d}-$ domestic price of the product $i$;

$P_{i}^{r}-$ world market price of the product $i$.

\section{RESULTS}

The grain market of Ukraine is one of the main segments of the agro-food market, which state determines the country's food security, the results of economic activity of agricultural producers and, in general, the welfare of the Ukrainian people.

The formation of the mechanism of state regulation of the grain market in Ukraine took place in several stages: in 2000-2008, the strengthening of regulatory influence; 2008-2010 liberalization as a result of Ukraine's accession to the World Trade Organization (WTO), high yields and activity of grain business players; 2010-2011 - introduction of a mechanism for export quotation. From 2014, a new stage of deregulation of the grain market has come to the end, which resulted in the abolition of the mandatory quarantine certificate for internal grain transportation, cancelled 14 permits, 6 licenses, introduced more than 50 other changes. From 1 January 2017, all grain market participants work in conditions of complete cancellation of special regime of VAT, and from 1 April 2017 - its automatic compensation for exporters was introduced.

According to the data of Table 1 the gross grain harvest in Ukraine on average for 2015-2017 has almost doubled in comparison with 2000-2002, mainly due to increase in average yield from 24.6 to 43.2 center per 1 ha.
Among the main grain crops, the largest increase in gross volumes was achieved in corn. Thus, during the study period, it increased by 6.5 times, having overcome a 30-millionth cut in individual harvest years. This was facilitated by the expansion of the collected area from an average of 1.2 million ha in 2000-2002 to 4.3 million ha in 2015-2017, with an increase of almost twice the average yield. Moreover, the range of corn spreading through the development of breeding and the introduction of new technologies now covers virtually all natural and climatic zones of Ukraine.

Among the main grain crops, the largest increase in gross volumes was achieved in corn. Thus, during the study period, it increased by 6.5 times, having overcome a 30 -millionth cut in individual harvest years. This was facilitated by the expansion of the collected area from an average of 1.2 million ha in 2000-2002 to 4.3 million ha in 2015-2017, with an increase of almost twice the average yield. Moreover, the range of corn spreading through the development of breeding and the introduction of new technologies now covers virtually all natural and climatic zones of Ukraine (Table 1).

In the structure of grain and legume production in Ukraine over the analysed period, agricultural enterprises produce about $80 \%$ of the total volume, including farms $-12-13 \%$, respectively, $20 \%$ belong to households, which mainly grow a considerable part of oats, millet and rye and buckwheat.

At the same time, large enterprises are oriented mainly on export types of grain crops (corn, wheat), which are more profitable from the point of view of profit and accordingly require more investment of resources per hectare of area (Kozak and Hryshchenko, 2016).

Analysing the current grain market, it is necessary to pay attention to the uneven development and imbalance of demand and supply in the context of individual grain crops. In particular, if in the last 5 marketing years in Ukraine the supply of wheat and maize has a tendency to increase, then rye - decreased by almost half, oats - by $25 \%$.

The main areas of use of grain within the state are the formation of a consumption fund, a feed and seed fund, food production and industrial processing of grain (Table 2). 
Proceedings of the 2019 International Scientific Conference 'Economic Sciences for Agribusiness and Rural Economy' No 3, Warsaw, 5-7 June 2019, pp. 67-75

Table 1. Gross production, collected area and yield of main grain crops of Ukraine on average over the period 2000-2017

\begin{tabular}{|l|r|r|r|r|r|r|r|}
\hline Specification & $2000-2002$ & $2003-2005$ & $2006-2008$ & $2009-2011$ & $2012-2014$ & $2015-2017$ \\
\hline \multicolumn{7}{|c|}{ Grains and legumes } \\
\hline Gross production (thous. t) & 34323.0 & 33353.0 & 38947.7 & 47348.7 & 57708.9 & 62710.2 \\
\hline Harvested area (thous. t) & 13828.0 & 13498.0 & 14333.5 & 15122.2 & 15074.6 & 14512.8 \\
\hline Yield (center/ha) & 24.6 & 24.2 & 26.8 & 31.2 & 38.3 & 43.2 \\
\hline \multicolumn{7}{|c|}{ Wheat } \\
\hline Grain production (thous. t) & 17367.0 & 13272.9 & 17923.5 & 20020.4 & 20718.6 & 26244.5 \\
\hline Harvested area (thous. t) & 6264.5 & 4853.7 & 6172.0 & 6564.8 & 6068.8 & 6463.3 \\
\hline Yield (center/ha) & 27.1 & 24.9 & 28.5 & 30.4 & 34.0 & 40.7 \\
\hline \multicolumn{7}{|c|}{ Corn } \\
\hline Grain production (thous. t) & 3889.7 & 7636.2 & 8431.2 & 15092.4 & 26802.6 & 25357.0 \\
\hline Harvested area (thous. t) & 1196.8 & 1982.6 & 2021.1 & 2760.1 & 4608.6 & 4272.1 \\
\hline Yield (center/ha) & 32.6 & 38.8 & 41.1 & 53.3 & 57.9 & 59.4 \\
\hline \multicolumn{7}{|c|}{ Barley } \\
\hline Grain production (thous. t) & 9140.5 & 8964.2 & 9977.8 & 9805.2 & 7848.0 & 8669.7 \\
\hline Harvested area (thous. t) & 3920.9 & 4488.7 & 4497.3 & 4331.5 & 3176.4 & 2722.0 \\
\hline Yield (center/ha) & 23.2 & 20.0 & 22.2 & 22.7 & 24.9 & 31.9 \\
\hline
\end{tabular}

Source: calculated on the basis of Prokopenko (2017).

Table 2. Balance of grain and leguminous crops, including grain processing products in terms of grain in 2000 , 2005, 2010, 2013-2017

\begin{tabular}{|l|r|r|r|r|r|r|r|r|}
\hline Specification & \multicolumn{1}{|c|}{2000} & \multicolumn{1}{|c|}{2005} & \multicolumn{1}{c|}{2010} & 2013 & \multicolumn{1}{c|}{2014} & \multicolumn{1}{c|}{2015} & \multicolumn{1}{c|}{2016} & 2017 \\
\hline Production (thous. t) & 24459 & 38016 & 39271 & 63051 & 63859 & 60126 & 66088 & 61917 \\
\hline Carry out (thous. t) & 1329 & -314 & -2054 & 6933 & 2977 & -3204 & 2130 & -1465 \\
\hline Import (thous. t) & 1010 & 226 & 175 & 242 & 263 & 190 & 240 & 255 \\
\hline Total supply (thous. t) & 24140 & 38556 & 41500 & 56360 & 61145 & 63520 & 64198 & 63637 \\
\hline Export (thous. t) & 1330 & 12650 & 14239 & 27836 & 33423 & 38338 & 41451 & 42499 \\
\hline Feed use (thous. t) & 11056 & 13817 & 14787 & 16183 & 15678 & 14189 & 12278 & 11011 \\
\hline Seeds (thous. t) & 3597 & 3294 & 3222 & 2890 & 2883 & 2597 & 2330 & 2120 \\
\hline Losses (thous. t) & 309 & 375 & 794 & 1506 & 1593 & 1400 & 1350 & 1106 \\
\hline Industrial use (thous. t) & 100 & 670 & 1650 & 1367 & 1281 & 1089 & 1044 & 1246 \\
\hline Consumption (thous. t) & 7748 & 7750 & 6808 & 6578 & 6224 & 5897 & 5745 & 5655 \\
\hline Consumption per capita (kg) & 124.9 & 123.5 & 111.3 & 108.4 & 108.5 & 103.2 & 101.0 & 100.8 \\
\hline
\end{tabular}

Source: calculated on the basis of State Statistics Service of Ukraine (2018). 
In the structure of grain consumption, the largest share is feed and food consumption. The decline in livestock in Ukraine in recent years is offset by an increase in the number of poultry. Given the above, feed is used in absolute values at the level of 11-15 million $t$, but relative - we tend to reduce. In particular, in 2017, it was $17.3 \%$, compared to 2016 - $19.1 \%$, in $2015-22.3 \%$. Food consumption of grain is relatively stable, although in recent years there has been a tendency to decrease it. The main reasons include: reduction of the population; leaving a significant number of our citizens to work abroad; more economical attitude to bakery products; change in diet.

The analysis shows that an increase in grain production is accompanied by an increase in its export potential. Over the past two years, Ukraine has been exporting record grain volumes - more than 40 million $t$. However, this is not always reflected in the increase in currency earnings. For example, in the wake of 2016, Ukraine exported a record volume of grain crops -41.5 million $\mathrm{t}$, which is almost $8 \%$ higher than exports in 2015. But due to lower world prices for raw materials, record volumes of grain exports from Ukraine in 2016 did not bring record earnings. It re- mained at almost the level of 2015 - about 6.1 billion USD. The quality of products is also a major problem in exporting grain crops. According to the results of $2016,57.0 \%$ of the wheat sold outside the state is forage. That is, the share of non-food grain, which is reflected in the price and accordingly in export earnings, is increasing.

The research has shown that price instability in the grain market indicates a lack of effective state regulation. In particular, the following manifestations of such imperfection include: instability of prices and incomes of commodity producers; not entirely predictable state policy; it is not always possible to balance the interests of the main market participants (producers, consumers and the state).

The obtained value of the indicator "market price support" for wheat growers in Ukraine in 2000-2017 indicates a significant amount of shortfall in gross transfers from consumers and taxpayers (Fig. 2).

The obtained values of the indicator the manufacturer's nominal producer protection coefficient (defined as the ratio of the domestic purchase price to the world price) for grain producers is confirmed by price instability and insufficient efficiency of the mechanism of grain market regulation in Ukraine.

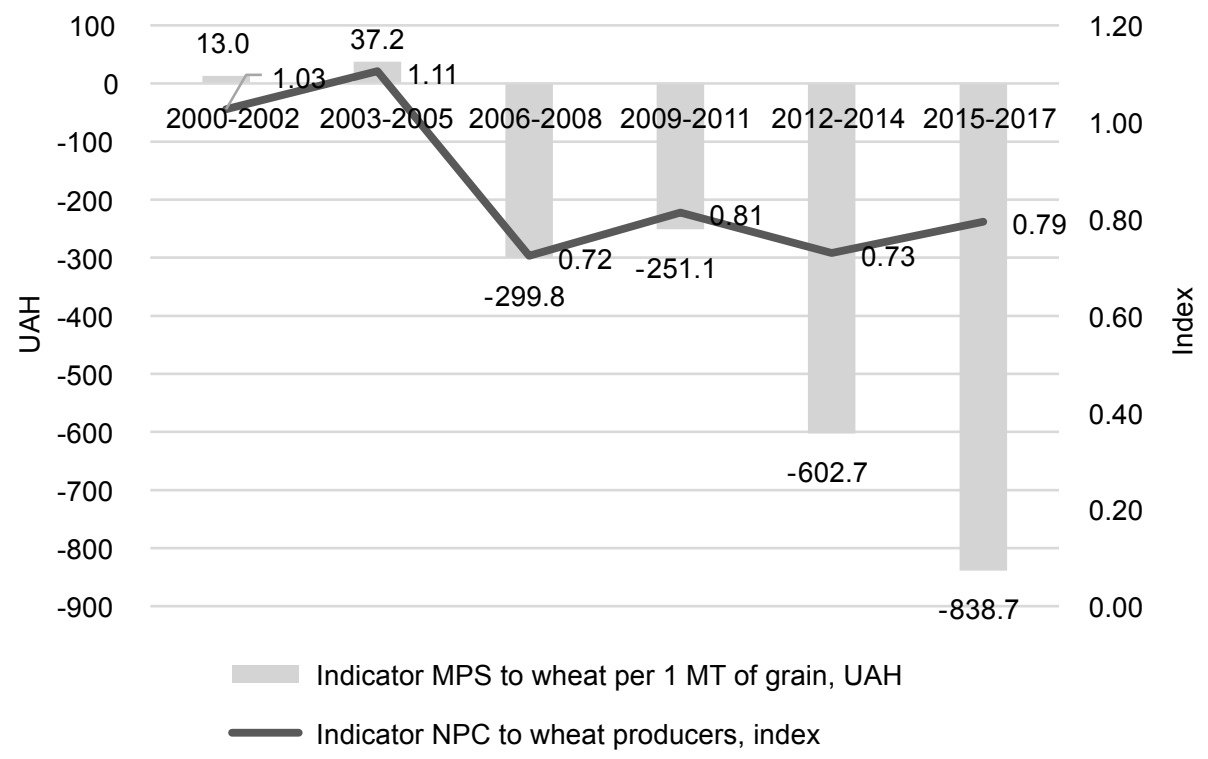

Figure 2. Indicators "nominal producer protection coefficient" (NPC) and "market price support" (MPS) of wheat producers in Ukraine per $1 \mathrm{t}$ of grain per average period

Source: calculated on the basis of Prokopenko (2018). 
In particular, as the competitiveness of domestic grain on the world market is ensured by lower grain prices, wheat exporters (grain traders) compensate for their price losses due to lower grain quality and logistic costs due to low purchasing prices. According to the calculations, wheat purchasing prices at the enterprise level on average for 2015-2017 in Ukraine were $21 \%$ lower than the world average. At the same time, agricultural commodity producers in turn compensate for price losses due to the low cost of land lease and wages of employees. Therefore, further increase in grain production in Ukraine needs a reduction in logistics costs due to the development of the transport and logistics infrastructure of the grain market in the medium and long term. Under these conditions, an important task of the state agricultural policy is the formation of a system of regulation of agro-food markets based on the expansion of the forecasting horizon.

Based on the second order polynomial trend extrapolation method developed forecasts of gross harvest of grain and leguminous and domestic consumption of grain and forage for food purposes in Ukraine until 2025 (Fig. 3).
Output data for forecasting the gross production of grains and legumes, as well as grain consumption for food purposes and feed costs were selected for the period from 2005-2016, according to the State Statistics Service of Ukraine. The predicted results showed that the production potential of grains by 2025 could potentially be around 100 million $t$, without structural changes in agricultural development, the consumption of grain in Ukraine would be reduced in favour of its exports. As a result, it can lead to deepening both transport and logistics and other problems of the development of the grain industry. The calculations have shown that Ukraine has a potential for increasing grain production and, accordingly, an increase in exports to 60-70 million t. At the same time, farmers must do everything necessary for the production of high quality grain.

Analysis has shown that the central link in the regulation of the grain market is its price, which should balance the interests of producers and consumers, exporters and importers. Especially acute imbalance of these interests manifests itself in the context of the financial and economic crisis.

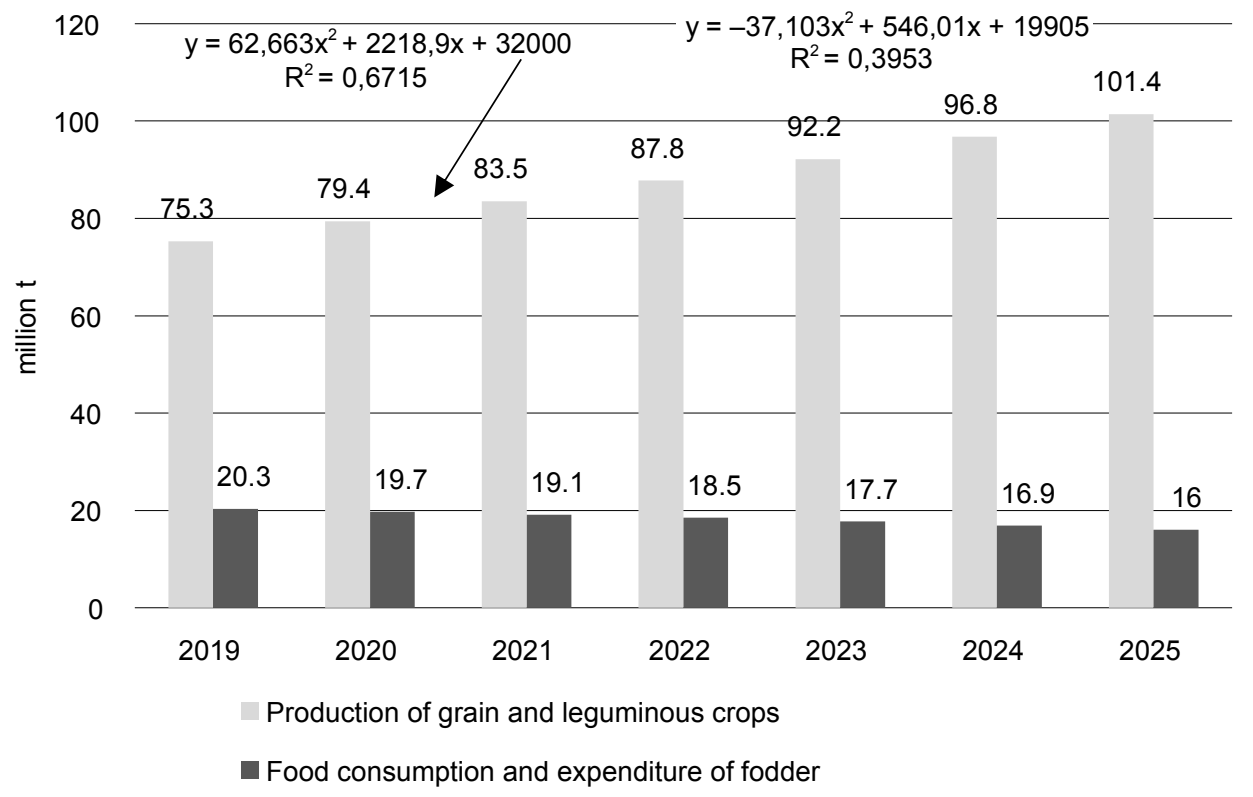

Figure 3. Forecasting of gross production of grain and legumes and grain consumption for food purposes and feed costs in Ukraine for the period till 2025

Source: calculated on the basis of Prokopenko (2018). 
To substantiate the state management decisions in the field of agricultural production regulation, it is important and necessary to have predictions of grain prices both on the world market and on the domestic market. However, in Ukraine, the forecast of grain prices is complicated not only by price volatility, but also by the devaluation of the national currency. Therefore, in our view, in order to take into account the influence of inflation, as well as the specificity of grain production, in particular the time lag between the costs incurred and the financial results obtained, we should use the indicator of the level of profitability of grain production. The value of this indicator makes it possible to compare income (profit) and expenses in the production of grain, to answer the question whether the current procurement price ensures the processes of reproduction in the industry. Since the value of economic variables is determined, as a rule, by not one and a few factors, one of the most effective ways of measuring their quantitative effect on the resultant sign is the use of multiple linear regression.

The basis of the proposed model is the interaction of demand (domestic consumption and exports), offers (gross production due to harvested areas and yields, imports, stocks), inflation and average annual prices, and their impact on the production efficiency of wheat. With the help of multiple linear regression, the factors that most affect the level of profitability of wheat production are determined $(\hat{y})$.

The equation of multiple linear regression for the abovementioned parameters for wheat grain in Ukraine for the period from 2000/01 MY to 2016/17 MY is:

$$
\begin{aligned}
\hat{y}= & -61.3-0.02 x_{1}-2.27 x_{2}+0.016 x_{3}- \\
& -0.014 x_{4}-0.01 x_{5}+0.014 x_{6}+0.002 x_{7}+ \\
& +0.99 x_{8}
\end{aligned}
$$

which:

$\hat{y}$ - profitability level (\%);

$x_{1}-$ harvested area (thous. ha);

$x_{2}-\operatorname{yield}($ center/ha);

$x_{3}$ - average price of $1 \mathrm{t}(\mathrm{UAH})$;

$x_{4}$ - stocks (thous. t);

$x_{5}$ - import (thous. t); $x_{6}-$ domestic consumption (thous. t);

$x_{7}-$ export (thous. $\mathrm{t}$ );

$x_{8}-$ inflation level (\%).

The coefficient of the multiple correlation is 0.888 (value from 0 to 1 ), which means an extremely high correlation between the predicted level of profitability for wheat grain and the linear combination of the above parameters. The statistical significance of the result is confirmed by a high determination coefficient of $\mathrm{R}^{2}=0.777$ and suggests that the regression is explained by the $77.7 \%$ variance of the value of the formation of the average annual price for wheat grain. The results obtained are fully consistent with the provisions of the law of demand and supply.

Taking into account the increase of export volumes of grain in recent years and the export orientation of the Ukrainian grain market in general, port grain terminals have become the key subject of the transport and logistics system. The analysis shows that the transport infrastructure does not meet the needs of the domestic market due to the operation of the railway transport, the unsatisfactory condition of individual sections of the connecting roads of the regions with the Black Sea ports, undeveloped river transport. This can be accompanied by high tariffs for transportation, in particular, the level of costs for agrarian logistics in Ukraine far exceeds the relevant indicators in developed countries exporting grain. In particular, calculations of infrastructure costs when exporting grain from Ukraine are on average about $600 \mathrm{UAH}$ per $1 \mathrm{t}$, or about $15 \%$ of all costs (Table 3 ).

In order to increase the efficiency of transport and logistics infrastructure, it is necessary to establish clear and transparent "rules of the game" in the market, which will stimulate competition and attract private investments to develop the objects of logistic infrastructure, development of river transport infrastructure. It is also necessary to establish clear rules and tariffs for the use of railway infrastructure, stimulate investment attraction in upgrading capacity for storage and handling of grain, automation of transport and logistics processes, which will allow not only to improve the efficiency of the logistics system, but also provide the required speed of transportation of significant volumes of grain. 
Proceedings of the 2019 International Scientific Conference 'Economic Sciences for Agribusiness and Rural Economy' No 3, Warsaw, 5-7 June 2019, pp. 67-75

Table 3. Infrastructure costs for grain exports (FOB terms) as of June 2017

\begin{tabular}{|c|c|c|c|}
\hline Costs & Standard (methodology) of calculation & $\begin{array}{c}\text { Cost per } 1 \mathrm{t} \text { of } \\
\text { grain } \\
(\mathrm{UAH})\end{array}$ & $\%$ \\
\hline $\begin{array}{l}\text { Transportation costs* } \\
\text { (by rail to the seaport) }\end{array}$ & $\begin{array}{l}489 \mathrm{~km} \text { at the tariff } \\
\text { of Ukrzaliznytsia with VAT }\end{array}$ & 256.80 & 42.7 \\
\hline Ship loading on port & $12 \mathrm{USD} / \mathrm{t}$ & 322.56 & 53.6 \\
\hline \multicolumn{2}{|l|}{ Total cost of certificates, total, including: } & 17.06 & 2.8 \\
\hline certificate of origin & $\begin{array}{l}\text { is included in the cost } \\
\text { of loading services }\end{array}$ & - & - \\
\hline $\begin{array}{l}\text { quality certificate (including cost } \\
\text { of analyses and work of survereur) }\end{array}$ & $0.3 \mathrm{USD} / \mathrm{t}$ & 1.43 & - \\
\hline fumigation certificate & $0.5 \mathrm{USD} / \mathrm{t}$ & 0.63 & - \\
\hline non-radioactive certificate & $\begin{array}{l}\text { is included in the cost } \\
\text { of loading services }\end{array}$ & 15.00 & - \\
\hline phytosanitary certificate & $\begin{array}{l}\text { is included in the cost } \\
\text { of loading services }\end{array}$ & - & - \\
\hline Cargo customs declaration & 150 USD & 5.58 & 0.9 \\
\hline \multicolumn{2}{|l|}{ Total cost } & 602.00 & 100.00 \\
\hline
\end{tabular}

Source: calculated according to the data of Ukrainian sea ports authority (2019).

\section{CONCLUSIONS}

Positive tendencies to increase the volumes of production and export of grain observed in recent years in Ukraine are accompanied by instability of commodity producers' prices and revenues, monopolization of the market and over-concentration of production by large companies, uneven distribution of market gain, it is not always possible to balance the interests of the main market participants (producers, consumers and the state) poses a threat to food security and negatively affects the development of the grain market.

Constraining factors for grain exports is the domestic transport and logistics infrastructure, which works with low efficiency of processing and transportation of grain. In particular, the cost of grain logistics from the producer in Ukraine to the ports in the Black Sea is approximately $40 \%$ higher than the cost of similar costs in France or Germany, and 30\% - than in the United States. Therefore, the contradiction between the rates of development of the grain industry and transport and logistics infrastructure becomes an urgent problem and needs to be solved at the state level through the improvement of the mechanism of regulation of the grain market.

In addition, the development of grain logistics infrastructure provides job creation, added value of products, which contributes to increasing revenues in the state and local budgets. Consequently, the reform of state regulation should be comprehensive and aimed at eliminating the barriers to private companies operating in the market of agrarian logistics and having the desire to invest in infrastructure upgrades.

\section{REFERENCES}

1. Derzhavna sluzhba statystyky Ukrayiny [State Statistics Service of Ukraine] (2018). Balans ta spozhyvannya osnovnykh kharchovykh produktiv naselennyam Ukrayiny. Statystychnyy zbirnyk [Balances and consumption of the main food products by the population of Ukraine. Statistical yearbook]. Kyiv. 
Proceedings of the 2019 International Scientific Conference 'Economic Sciences for Agribusiness and Rural Economy' No 3, Warsaw, 5-7 June 2019, pp. 67-75

2. Josling, T.E. (1973). Agricultural Protection: Policy and International Trade. FAO, Rome.

3. Kozak, O.A., Hryshchenko, O.Y. (2016). Rozvytok zernovoyi haluzi Ukrayiny na suchasnomu etapi [Development of the grain industry of Ukraine at the present stage]. Ekonomika APK, 1, pp. 38-47.

4. Organization for Economic Co-operation and Development (2018). Retrieved from: http://www.oecd.org/ dataoecd/36/47/1937457.pdf [Accessed 04.03.2019].

5. Prokopenko O.M. (2018). Roslynstvo [Ukraine's crop production]. In: Sil's'ke hospodarstvo Ukrayiny 2017. Statystychnyy zbirnyk [Agriculture of Ukraine 2017. Statistical yearbook]. Kyiv, pp. 89-130.
6. State Statistics Service of Ukraine (2019). Retrieved from: http://ukrstat.gov.ua [Accessed 05.03.2019].

7. Tsakok, I. (1990). Agricultural Price Policy: A Practitioner's Guide to Partial - Equilibrium Analysis. Cornell University Press, New York.

8. Ukrainian sea ports authority (2019). Retrieved from: http://www.uspa.gov.ua [Accessed 04.03.2019].

9. Webb, A.J., Lopes, M., Penn, R. (1990). Estimates of Producer and Consumer Subsidy Equivalents. Government Intervention in Agriculture. 